\title{
Willingness of Patients with Breast Cancer in the Adjuvant and Metastatic Setting to Use Electronic Surveys (ePRO) Depends on Sociodemographic Factors, Health-related Quality of Life, Disease Status and Computer Skills
}

\author{
Die Bereitschaft zur Nutzung von technikbasierten Erhebungen (ePRO) bei Patientinnen mit Mammakarzinom \\ in der adjuvanten und metastasierten Situation in Abhängigkeit von soziodemografischen Merkmalen, \\ gesundheitsbezogener Lebensqualität, Erkrankungsstatus und Technikskills
}

Authors

Affiliations
J. Graf ${ }^{1,2,3}$, E. Simoes ${ }^{1,2,4}$, K. Wißlicen ${ }^{1}$, L. Rava ${ }^{1}$, C. B. Walter ${ }^{1}$, A. Hartkopf ${ }^{1}$, L. Keilmann ${ }^{5}$, A. Taran ${ }^{1}$, S. Wallwiener ${ }^{1}$, P. Fasching ${ }^{6}$, S. Y. Brucker ${ }^{1,2}$, M. Wallwiener $^{5}$

The affiliations are listed at the end of the article.

\section{Key words}

- breast cancer

- metastatic setting

- patient-reported outcomes

- acceptance of technologybased surveys

- obstacles

\section{Schlüsselwörter}

- Brustkrebs

- metastasierte Situation

- Patient-reported Outcomes

- Akzeptanz von technik-

basierten Erhebungen

- Hürden

Deutsche Version unter: http://dx.doi.org/ $10.1055 / \mathrm{s}-0042-105872$

$\begin{array}{ll}\text { received } & 1.3 .2016 \\ \text { revised } & 1.4 .2016 \\ \text { accepted } & 1.4 .2016\end{array}$

Bibliography

Dol http://dx.doi.org/ 10.1055/s-0042-105872

Geburtsh Frauenheilk 2016; 76: 535-541 (c) Georg Thieme

Verlag KG Stuttgart · New York . ISSN 0016-5751

\section{Correspondence}

Joachim Graf, M.A.

Department für

Frauengesundheit

Universitätsklinikum Tübingen

Calwerstraße 7

72076 Tübingen

joachim.graf@

med.uni-tuebingen.de

\section{Abstract}

$\nabla$

Introduction: Because of the often unfavorable prognosis, particularly for patients with metastases, health-related quality of life is extremely important for breast cancer patients. In recent years, data on patient-relevant endpoints is being increasingly collected electronically; however, knowledge on the acceptance and practicability of, and barriers to, this form of data collection remains limited.

Material and Methods: A questionnaire was completed by 96 patients to determine to what extent existing computer skills, disease status, health-related quality of life and sociodemographic factors affect patients' potential willingness to use electronics methods of data collection (ePRO).

Results: 52 of 96 (55\%) patients reported a priori that they could envisage using ePRO. Patients who a priori preferred a paper-based survey (pPRO) tended to be older (ePRO 53 years vs. pPRO 62 years; $p=0.0014$ ) and typically had lower levels of education $(p=0.0002)$, were in poorer health $(p=0.0327)$ and had fewer computer skills $(\mathrm{p}=0.0003)$.

Conclusion: Barriers to the prospective use of ePRO were identified in older patients and patients with a lower quality of life. Given the appropriate conditions with regard to age, education and current health status, opportunities to participate should be provided to encourage patients' willingness to take part and ensure the validity of survey results. Focusing on ease of use of ePRO applications and making applications more patient-oriented and straightforward appears to be the way forward.

\section{Zusammenfassung \\ $\nabla$}

Einleitung: Aufgrund der häufig ungünstigen Prognose insbesondere in der metastasierten Situation ist die gesundheitsbezogene Lebensqualität bei Brustkrebspatientinnen von großer Bedeutung. Seit einigen Jahren werden patientenrelevante Endpunkte zunehmend auch technikbasiert erhoben, der Wissensstand zu Akzeptanz, Praktikabilität und Hürden ist jedoch bislang begrenzt. Material und Methoden: Anhand einer Fragebogenerhebung mit $n=96$ Patientinnen wurde untersucht, inwiefern vorhandene Technikskills, der Erkrankungsstatus, die gesundheitsbezogene Lebensqualität und soziodemografische Faktoren die potenzielle Bereitschaft zur Nutzung technikbasierter Erhebungen (ePRO) beeinflussen.

Ergebnisse: Insgesamt gaben 52/96 (55\%) der Patientinnen an, sich a priori eine Teilnahme an ePRO vorstellen zu können. Patientinnen, die a priori eine papierbasierte Befragung (pPRO) wünschten, waren älter (ePRO 53 Jahre vs. pPRO 62 Jahre $p=0,0014$ ) und waren durch einen niedrigeren Bildungsstatus $(p=0,0002)$, einen schlechteren Gesundheitszustand ( $p=0,0327)$ und geringere Technikskills $(\mathrm{p}=0,0003$ ) charakterisiert.

Schlussfolgerung: Bei Patientinnen mit höherem Alter und niedrigerer Lebensqualität konnten Hürden für eine prospektive ePRO-Teilnahme identifiziert werden. Bei entsprechenden Vorbedingungen das Alter, den Bildungsstatus und den aktuellen Gesundheitszustand betreffend, sollten Möglichkeiten der Unterstützung angeboten werden, um die Bereitschaft zur Teilnahme bzw. die Validität der Ergebnisse sicherzustellen. Sinnvoll erscheint weiterhin, die Handhabbarkeit von ePRO-Applikationen zu fokussieren und patientinnenorientiert erleichternd zu gestalten. 


\section{Introduction}

\section{$\nabla$}

Despite recent advances in surgery, chemotherapy, and other forms of support, metastatic breast cancer remains a challenge for gynecologic oncology [1-3]. The mean life expectancy of these patients is 3 years and depends on tumor biology and the degree and site of metastasis, and the 5-year survival rate is 25 to $30 \%$ [4-11]. This means that the prognosis for these patients is significantly worse than that of patients in the adjuvant setting. The mean 5-year survival rate for all patients with breast cancer is currently around $80 \%$ [12-16]. For patients with metastases, palliative care may often be the only choice, with the remaining therapy options aiming to extend the patient's survival time while remaining largely free of tumor-related symptoms. This is why health-related quality of life should always be included in therapy planning [17-25]. In the medium or longer term, systemic chemotherapy may also reduce the health-related quality of life of patients receiving adjuvant treatment [26-28].

Measuring the health-related quality of life of patients with metastatic breast cancer is very relevant, and not merely for healthcare research. According to the German Act on the Reform of the Market for Medicinal Products (Arzneimittel-Neuordnungsgesetz [AMNOG]), the proof of the benefit of therapeutic interventions must be based on patient-relevant endpoints and should include various aspects which show "how the patient feels, how he is able to perform functions and activities, and whether he survives" (AMNOG 2010; §35a SGB V and Code of Procedure of the Federal Joint Commission [G-BA-Verfahrensordnung], §13) [29]. The measured variables used to assess the benefit (e.g. health-related quality of life) are referred to as patient-reported outcomes (PRO) and reflect the patient's subjective perception of her own state of health without evaluation by a third party [30, 31]. Particularly in oncology patients, the patient's subjective perception of her own state of health is considered an important indication of the efficacy of a specific therapy [32-34].

Paper-based surveys still predominate; electronic methods to collect PROs (e.g. with tablet PCs) have only begun to be used in recent years. But knowledge about the acceptance and practicability of this method of data collection remains limited [32,3542]. To date, there has been no study which has attempted to identify possible barriers to the use of electronic surveys which could arise from the side-effects of therapy or be due to aspects of the patient's biography. This lack result in a consistent bias in such surveys, as it is unclear whether insufficient computer skills, therapy-related barriers or other prerequisites necessary to complete an electronic survey might alter the response or even result in a refusal to participate in the survey, i.e., whether there are barriers which could influence the survey outcome. This study looked at whether previous experience of using a tablet or the internet (computer skills), disease status, patients' health-related quality of life and the sociodemographic variables "level of education" and "age" influenced the willingness of breast cancer patients with metastasis or receiving adjuvant treatment to use electronic surveys. The hypothesis was that older patients in a poorer state of health and a lower health-related quality of life faced greater barriers and required more support compared to younger patients in a better state of health, which is why particularly older and more ill patients may be less willing to complete ePRO questionnaires (e.g. using a tablet).

\section{Patients/Material and Methods}

$\nabla$

Sample and study design

In summer 2015, 96 breast cancer patients with metastasis or receiving adjuvant therapy and treated consecutively at the University Gynecological Hospital in Tübingen completed a survey using a paper-based questionnaire. A total of 120 patients were asked to participate in the survey, resulting in a response rate of $80 \%$. 65 patients (68\%) had metastases and 31 patients (32\%) were receiving adjuvant therapy. The data collected from the two patient groups were combined for statistical analysis. Patients completed the questionnaire during an outpatient visit to the hospital under the supervision of an attending physician. Patients were informed prior to completing the questionnaire about the aims of the study and that participation in the study was voluntary. The ethics committee gave its prior consent to the study (project number 196/2015B02). All female breast cancer patients aged more than 18 years who either had metastasis or were undergoing adjuvant treatment and who additionally had sufficient knowledge of German to answer the questionnaire were included in the study.

\section{Questionnaire}

The survey consisted of three parts. The first part focused on the patients' socio-economic variables. The second part asked patients about their health-related quality of life and overall state of health. The survey questionnaires EORTC QLQ-C30 and EQ VAS (EQ-5D-5L) were used for this second part [43-46]; the questionnaires had already been previously approved for use in a parallel study (project number 234/2014BO1). The third part consisted of an additional questionnaire consisting of validated "partial" questionnaires which had been developed to examine our study questions. In this third part of the survey patients were asked to provide information about their use of electronic technology at home, to evaluate their knowledge and understanding of computers and the internet and comment on their general attitude toward electronically-based surveys. EORTC QLQ-C30 is a diseasespecific questionnaire, the use of which has already been validated in research. It consists of 5 subscales, various symptom scales, and individual items which aim to capture the patients' quality of life on a multidimensional level $[43,44]$. The generic EQ-5D-5L questionnaire evaluates quality of life in five dimensions using a five-step scale and the EQ VAS scale, with the current state of health recorded as a number $(0=$ worst imaginable state of health, 100 = best imaginable state of health) $[45,46]$. To evaluate quality of life, patients were surveyed using the EQ VAS scale which was combined with two questions from the EORTC QLQ-C30, and responses to questions about the patient's current health status and current quality of life were recorded using a seven-step Likert scale (from 1 = very poor to 7 = excellent). Calculations of mean values were done in accordance with the official EORTC guidelines which require a separate score to be calculated for each scale, with scores taking any value between 0 and 100 [47].

The additional questions on the patient's computer skills and needs based on their prior experience of digital media consisted of: the modules on the private use of technology from the KBF-BK questionnaire [48]; published, validated items of a survey on the acceptance and reliability of electronic psycho-oncologic screening [40]; and additional questions, developed by the authors, on the aspects "technical barriers" and "potential (technological) support structures which would take the patient's prior experience of technological research tools into account" $[49,50]$. 
Table 1 Sociodemographic characteristics of the patient cohort.

\begin{tabular}{|c|c|}
\hline Sociodemographic variables & Total \\
\hline \multicolumn{2}{|l|}{ Age } \\
\hline mean (median) & $56.68(54)$ \\
\hline - standard deviation (range [min; max]) & $12.38(60[20 ; 85])$ \\
\hline \multicolumn{2}{|l|}{ Highest level of education achieved } \\
\hline - left school without any qualifications $(=1)$ & $\mathrm{n}=1(1 \%)$ \\
\hline - qualified certificate of secondary education (=2) & $\mathrm{n}=31(32 \%)$ \\
\hline - general certificate of secondary education $(=3)$ & $\mathrm{n}=28(29 \%)$ \\
\hline $\begin{array}{l}\text { - entrance qualification for an advanced technical } \\
\text { college }(=4)\end{array}$ & $n=15(16 \%)$ \\
\hline entrance qualification for university $(=5)$ & $n=13(14 \%)$ \\
\hline not specified & $\mathrm{n}=8(8 \%)$ \\
\hline \multicolumn{2}{|l|}{ Currently working } \\
\hline yes, full time & $\mathrm{n}=11(12 \%)$ \\
\hline yes, part time & $\mathrm{n}=31(32 \%)$ \\
\hline no & $n=43(45 \%)$ \\
\hline not specified & $\mathrm{n}=11(11 \%)$ \\
\hline \multicolumn{2}{|l|}{ Disease/therapy status } \\
\hline metastasis & $n=65(68 \%)$ \\
\hline adjuvant & $\mathrm{n}=31(32 \%)$ \\
\hline
\end{tabular}

\section{Statistical analysis}

A frequency analysis was done with MS Excel 2010 and IBM SPSS 21 to determine the descriptive characteristics of the collected data. Differences were identified using unpaired bilateral t-tests. A bilateral p-value of $<0.05$ was considered statistically significant in all analyses $(\alpha=0.05)$. Pearson's correlation coefficient was calculated to show correlations between the variables "age", "level of education", "quality of life", "disease status" and "computer skills". All calculations were based on the assumption that data were normally distributed, and the Shapiro-Wilk test was used prior to the evaluation of data to verify the normal distribution of data.

\section{Results}

$\nabla$

\section{Sociodemographic variables}

- Table 1 shows the sociodemographic characteristics of the patient cohort. Mean age of the patients was 56.68 years (minimum: 20 years, maximum: 85 years). $30 \%$ of patients had higher educational qualifications (entrance qualification for an advanced technical college or for university), 42 patients (34\%) were working despite disease (at least part time).

\section{Health-related quality of life and disease status}

- Table 2 shows patients' health-related quality of life and current state of health. The median value for the patient's health status on the EQ VAS scale was 64.67 , with 60 as the most commonly reported value. The median state of health using the EORTC
Table 3 Computer skills and willingness to complete electronic PRO questionnaires in the total patient cohort.

\begin{tabular}{|c|c|}
\hline Computer skills & Total \\
\hline \multicolumn{2}{|c|}{ Computer skills (self-assessment by the patient) } \\
\hline Mean (standard deviation) & $2.33(0.75)$ \\
\hline beginner $(=1)$ & $\mathrm{n}=10(10 \%)$ \\
\hline - $\operatorname{basic}(=2)$ & $\mathrm{n}=37(39 \%)$ \\
\hline - advanced $(=3)$ & $\mathrm{n}=30(31 \%)$ \\
\hline - professional $(=4)$ & $n=4(4 \%)$ \\
\hline not specified & $\mathrm{n}=15(16 \%)$ \\
\hline \multicolumn{2}{|l|}{ Computer use (years) } \\
\hline Mean (median) & $16.73(15)$ \\
\hline Standard deviation (range [min; max]) & $8.25(34[2 ; 36])$ \\
\hline \multicolumn{2}{|l|}{ Internet use (years) } \\
\hline Mean (median) & $11.84(10)$ \\
\hline Standard deviation (range [min; max]) & $6.53(24[1 ; 25])$ \\
\hline \multicolumn{2}{|l|}{ Use of tablets } \\
\hline Mean (standard deviation) & $1.91(1.02)$ \\
\hline not at all & $\mathrm{n}=33(34 \%)$ \\
\hline very little & $\mathrm{n}=10(10 \%)$ \\
\hline - moderate & $\mathrm{n}=19(20 \%)$ \\
\hline a lot & $\mathrm{n}=4(4 \%)$ \\
\hline not specified & $\mathrm{n}=30(31 \%)$ \\
\hline \multicolumn{2}{|c|}{$\begin{array}{l}\text { Could you imagine completing an electronic questionnaire } \\
\text { on your subjective perception of your own state of health? }\end{array}$} \\
\hline - Yes & $\mathrm{n}=52(55 \%)$ \\
\hline$>$ No & $\mathrm{n}=35(37 \%)$ \\
\hline not specified & $\mathrm{n}=8(8 \%)$ \\
\hline \multicolumn{2}{|c|}{ Do you think that the introduction of electronic surveys will... } \\
\hline - improve hospital care & $\mathrm{n}=45(47 \%)$ \\
\hline worsen hospital care & $\mathrm{n}=11(11 \%)$ \\
\hline not specified & $\mathrm{n}=40(42 \%)$ \\
\hline \multicolumn{2}{|c|}{$\begin{array}{l}\text { Compared to a paper-based questionnaire, an electronic questionnaire } \\
\text { is ... less suitable }(=1) \text {, more suitable }(=5)\end{array}$} \\
\hline Mean (median) & $3.34(3)$ \\
\hline Standard deviation & 1.30 \\
\hline \multicolumn{2}{|c|}{$\begin{array}{l}\text { Compared to a paper-based questionnaire, an electronic questionnaire } \\
\text { is ... more tiring }(=1) \text {, less tiring }(=5)\end{array}$} \\
\hline Mean (median) & $3.22(3)$ \\
\hline Standard deviation & 1.21 \\
\hline \multicolumn{2}{|c|}{$\begin{array}{l}\text { Compared to a paper-based questionnaire, an electronic questionnaire } \\
\text { is ... more difficult }(=1) \text {, less difficult }(=5)\end{array}$} \\
\hline Mean (median) & $3.06(3)$ \\
\hline Standard deviation & 1.21 \\
\hline
\end{tabular}

QLQ-C30 was 56, while the mean score for quality of life for the overall patient cohort was 58 .

Computer skills: previous experience of digital media $34(35 \%)$ patients stated that they had advanced or professional computer skills while 47 (49\%) patients reported having poor to moderate computer skills. Five patients reported that they did not use either a computer or the internet. When asked about

Table 2 Quality of life and state of health of the total patient cohort.

\begin{tabular}{|c|c|c|c|c|c|}
\hline & \multirow[t]{2}{*}{$\begin{array}{l}\text { EQ VAS scale } \\
(n=96)\end{array}$} & \multicolumn{2}{|c|}{$\begin{array}{l}\text { EORTC QLQ-C30 (current state of health) } \\
(n=74)\end{array}$} & \multicolumn{2}{|c|}{$\begin{array}{l}\text { EORTC QLQ-C30 (current quality of life) } \\
(n=74)\end{array}$} \\
\hline & & Item value & Score value (in \%) & Item value & Score value (in \%) \\
\hline Mean (median) & $64.67(70)$ & $4.43(4)$ & $56.16(50)$ & $4.54(5)$ & 57.97 (66.67) \\
\hline Standard deviation & 18.15 & 1.32 & 23.56 & 1.31 & 23.50 \\
\hline Range (min; max) & $90(5 ; 95)$ & $6(1 ; 7)$ & $99(0 ; 100)$ & $6(1 ; 7)$ & $99(0 ; 100)$ \\
\hline
\end{tabular}


Table 4 Subgroup analysis according to the preferred method of survey (ePRO versus pPRO).

\begin{tabular}{|c|c|c|c|c|c|c|c|}
\hline & \multicolumn{2}{|c|}{$\begin{array}{l}\text { Electronic/tablet-based } \\
\text { survey welcomed }(n=52)\end{array}$} & \multicolumn{2}{|c|}{$\begin{array}{l}\text { Electronic/tablet-based } \\
\text { survey not welcomed } \\
(\mathrm{n}=35)\end{array}$} & \multirow[t]{2}{*}{ Difference } & \multirow[t]{2}{*}{$95 \% \mathrm{Cl}$} & \multirow[t]{2}{*}{$\begin{array}{l}\text { p-value } \\
(\alpha=0.05)\end{array}$} \\
\hline & Mean & SD & Mean & SD & & & \\
\hline Age & 53.24 & 9.03 & 61.86 & 15.1 & -8.62 & $-13.796 ;-3.43$ & 0.0014 \\
\hline State of health (EQ VAS) & 69.06 & 17.35 & 60.41 & 18.13 & 8.65 & $0.73 ; 16.58$ & 0.0327 \\
\hline State of health (EORTC QLQ-C30) & 60.09 & 20.70 & 53.79 & 22.38 & 6.2998 & $-5.14 ; 17.73$ & 0.2747 \\
\hline Quality of life (EORTC QLQ-C30) & 61.84 & 21.54 & 57.58 & 22.84 & 4.266 & $-7.54 ; 16.08$ & 0.4725 \\
\hline Level of education & 3.44 & 1.05 & 2.6 & 0.88 & 0.84 & $0.41 ; 1.27$ & 0.0002 \\
\hline no qualifications & $\mathrm{n}=0$ & & $\mathrm{n}=1($ & & & & \\
\hline $\begin{array}{l}\text { qualified certificate of } \\
\text { secondary education }\end{array}$ & $n=10(19 \%)$ & & $\mathrm{n}=19$ & & & & \\
\hline $\begin{array}{l}\text { general certificate of } \\
\text { secondary education }\end{array}$ & $n=19(37 \%)$ & & $\mathrm{n}=9$ ( & & & & \\
\hline $\begin{array}{l}\text { entrance qualification for an } \\
\text { advanced technical college }\end{array}$ & $n=10(19 \%)$ & & $\mathrm{n}=5($ & & & & \\
\hline - entrance qualification for university & $\mathrm{n}=11(21 \%)$ & & $\mathrm{n}=1($ & & & & \\
\hline not specified & $n=2(4 \%)$ & & $\mathrm{n}=0$ & & & & \\
\hline Computer skills & 2.56 & 0.66 & 1.94 & 0.7 & 0.61 & $0.29 ; 0.93$ & 0.0003 \\
\hline beginner & $n=1(2 \%)$ & & $\mathrm{n}=7$ ( & & & & \\
\hline basic & $n=22(42 \%)$ & & $\mathrm{n}=14$ & & & & \\
\hline advanced & $\mathrm{n}=23(44 \%)$ & & $n=6($ & & & & \\
\hline professional & $n=4(8 \%)$ & & $\mathrm{n}=0$ & & & & \\
\hline not specified & $n=2(4 \%)$ & & $\mathrm{n}=8$ & & & & \\
\hline
\end{tabular}

their use of tablets, 33 patients (34\%) used or had used tablets, 33 (34\%) did not use them, and 30 (31\%) did not specify their usage. - Table 3 shows the technology skills for the total patient cohort together with their disease-related use of computers.

Willingness to use electronic PRO questionnaires (ePRO) Patients were asked whether they could potentially imagine participating in electronic PRO surveys, whether they were of the opinion that using electronic surveys to record PRO would improve or worsen hospital care, and whether compared to paperbased questionnaires electronic questionnaires were - in their view - more suitable or less suitable, more exhausting or less exhausting, and more difficult or less difficult to complete ( Table 3). Overall, slightly more than half of all participants reported that they could imagine completing electronic surveys, while $37 \%$ stated that they did not wish to take part in such surveys. The question whether electronic surveys could have a positive impact on care was answered in the affirmative by 45 (47\%) patients. No differences between electronic questionnaires and paper-based questionnaires were found with regard to suitability, how tiring it was to complete the survey, or the survey's degree of difficulty.

Correlations between willingness to use technology and the variables "age", "level of education",

"quality of life", "health status" and "computer skills" Patients were divided into one of two subgroups to identify possible relationships between patients' computer skills, disease status, health-related quality of life and the sociodemographic factors "level of education" and "age" and patients' willingness to use electronic surveys. Table $\mathbf{4}$ shows the statistical differences between patients who rejected electronic surveys compared to those who were prepared to accept them. The patients in the subgroup who were prepared to record their subjective perception of their state of health using an electronic questionnaire were on average almost 9 years younger and had a higher level of education ( $40 \%$ either had an entrance qualification for an advanced technical college or an entrance qualification for university). They also assessed the state of their health (69.06 vs. $60.41 \%$ and 60.09 vs. $53.79 \%$, resp.), their quality of life $(61.84$ vs. $57.58 \%$ ) and their computer skills (2.56 vs. 1.94$)$ as higher compared to patients in the other subgroup. By comparison, patients who preferred a paper-based survey were older (mean age: 62 years), had on average a lower level of education, the state of their health was poorer and they had less previous experience with computers, the internet, or tablets. The differences between the two groups were statistically significant for the variables "age", "level of education", "state of health based on the EQ VAS scale" and "computer skills".

\section{Willingness correlated with state of health}

The total patient cohort was divided into two subgroups according to the patients' assessment of their own state of health evaluated using the EQ VAS scale. Subgroup 1 consisted of all patients who - on a scale from 0 to 100 - had reported their state of health as 60 or less; subgroup 2 consisted of patients in better health according to their own assessment. As shown in 0 Table 5, the willingness to use electronic surveys was significantly lower for patients in poorer health: only $40 \%$ of the patients in this subgroup were willing to complete a survey on the subjective perception of their own state of health electronically, while $70 \%$ of patients in better health were willing to do so. There were no other significant differences between the two subgroups with respect to other surveyed items.

Correlation analysis showed a moderate statistical correlation between the variable "age" and the willingness to use electronic means to complete a survey $(r=0.321, p=0.002)$ but showed no significant correlation for any of the other variables ( $\bullet$ Table 6 ). 
Table 5 Willingness to use electronic questionnaires: differences between subgroups.

\begin{tabular}{|c|c|c|c|c|c|c|c|}
\hline & \multicolumn{2}{|c|}{$\begin{array}{l}\text { State of health } \leq 60 \\
\text { (EQ VAS) }(n=40)\end{array}$} & \multicolumn{2}{|c|}{$\begin{array}{l}\text { State of health }>60 \\
\text { (EQ VAS) }(n=50)\end{array}$} & \multirow[t]{2}{*}{ Difference } & \multirow[t]{2}{*}{$95 \% \mathrm{Cl}$} & \multirow[t]{2}{*}{$\begin{array}{l}\text { p-value } \\
(\alpha=0.05)\end{array}$} \\
\hline & Mean & SD & Mean & SD & & & \\
\hline Age $^{1}$ & 54.81 & 13.81 & 56.72 & 10.58 & -1.92 & $-7.02 ; 3.19$ & 0.4574 \\
\hline $\begin{array}{l}\text { Compared to a paper-based questionnaire, } \\
\text { an electronic questionnaire is ... } \\
\text { less suitable }(=1) \text {, more suitable }(=5)^{1}\end{array}$ & 3.26 & 1.32 & 3.35 & 1.25 & -0.05 & $-0.7 ; 0.6$ & 0.8830 \\
\hline $\begin{array}{l}\text { Compared to a paper-based questionnaire, } \\
\text { an electronic questionnaire is ... } \\
\text { more tiring }(=1) \text {, less tiring }(=5)^{1}\end{array}$ & 3.27 & 1.15 & 3.11 & 1.24 & 0.16 & $-0.46 ; 0.78$ & 0.6034 \\
\hline $\begin{array}{l}\text { Compared to a paper-based questionnaire, } \\
\text { an electronic questionnaire is ... } \\
\text { more difficult }(=1) \text {, less difficult }(=5)^{1}\end{array}$ & 3.35 & 1.16 & 2.94 & 1.14 & 0.40 & $-0.19 ; 0.995$ & 0.1809 \\
\hline Computer skills $^{1}$ & 2.19 & 0.79 & 2.45 & 0.72 & -0.26 & $-0.61 ; 0.08$ & 0.1347 \\
\hline beginner & \multicolumn{2}{|c|}{$\mathrm{n}=6(15 \%)$} & \multicolumn{2}{|c|}{$\mathrm{n}=4(8 \%)$} & & & \\
\hline - basic & \multicolumn{2}{|c|}{$n=14(35 \%)$} & \multicolumn{2}{|c|}{$\mathrm{n}=20(40 \%)$} & & & \\
\hline advanced & \multicolumn{2}{|c|}{$\mathrm{n}=10(25 \%)$} & \multicolumn{2}{|c|}{$\mathrm{n}=19(38 \%)$} & & & \\
\hline professional & \multicolumn{2}{|c|}{$\mathrm{n}=1(3 \%)$} & \multicolumn{2}{|c|}{$\mathrm{n}=3(6 \%)$} & & & \\
\hline not specified & \multicolumn{2}{|c|}{$n=9(23 \%)$} & \multicolumn{2}{|c|}{$n=3(6 \%)$} & & & \\
\hline Willingness to use technology-based surveys² & & & & & & & 0.038 \\
\hline - yes & \multicolumn{2}{|c|}{$n=16(40 \%)$} & \multicolumn{2}{|c|}{$\mathrm{n}=35(70 \%)$} & & & \\
\hline$>$ no & \multicolumn{2}{|c|}{$\mathrm{n}=18(45 \%)$} & \multicolumn{2}{|c|}{$\mathrm{n}=14(28 \%)$} & & & \\
\hline not specified & \multicolumn{2}{|c|}{$\mathrm{n}=6(15 \%)$} & \multicolumn{2}{|c|}{$\mathrm{n}=1(2 \%)$} & & & \\
\hline $\begin{array}{l}\text { Do you think that the introduction of electronic } \\
\text { surveys will ...2 }\end{array}$ & & & & & & & 0.9144 \\
\hline improve hospital care & \multicolumn{2}{|c|}{$n=18(45 \%)$} & \multicolumn{2}{|c|}{$\mathrm{n}=25(50 \%)$} & & & \\
\hline worsen hospital care & \multicolumn{2}{|c|}{$n=4(10 \%)$} & \multicolumn{2}{|c|}{$\mathrm{n}=6(12 \%)$} & & & \\
\hline not specified & \multicolumn{2}{|c|}{$n=18(45 \%)$} & \multicolumn{2}{|c|}{$\mathrm{n}=19(38 \%)$} & & & \\
\hline
\end{tabular}

${ }^{1}$ t-test; ${ }^{2} x^{2}$ test

Table 6 Correlation analysis.

\section{Variables}

Age vs. willingness to participate in an electronic survey

Level of education vs. willingness to participate in an electronic survey

State of health (EQ VAS) vs. willingness to participate in an electronic survey

State of health (EORTC QLQ-C30) vs. willingness to participate in an electronic survey

LQ (EORTC QLQ-C30) vs. willingness to participate in an electronic survey

Computer skills vs. willingness to participate in an electronic survey

$\begin{array}{ll}\text { Correlation (Pearson) } & \text { Significance }(\boldsymbol{\alpha}=\mathbf{0 , 0 5}) \\ \mathbf{r}=\mathbf{0 . 3 2 1} & \mathbf{p}=\mathbf{0 . 0 0 2} \\ r=0.097 & \mathrm{p}=0.348 \\ r=-0.006 & \mathrm{p}=0.954 \\ r=-0.084 & \mathrm{p}=0.487 \\ r=-0.022 & \mathrm{p}=0.857 \\ r=0.116 & \mathrm{p}=0.263\end{array}$

\section{Discussion}

\section{$\nabla$}

In coming years, use of digital ePRO applications will become increasingly common in research and thus also in routine clinical practice. The data collected in this study show that, at present, it is primarily younger patients in better health who are spontaneously willing to participate in electronic surveys while the barriers to using electronic surveys are higher for older patients in a poorer state of health. Almost half of the patients clearly had no idea what was meant by the term "tablet". This is in stark contrast to previous findings which had postulated that EPROs were very feasible but without explicitly looking at existing computer skills [39-42]. It could be that a need for support exists, but this has still to be substantiated (publication in progress). Possible approaches could include training patients to use the technology or support offered by study nurses or, in special cases, by members of the patient's own family. The findings presented here expand the current understanding of this issue. Oncologic studies have shown that electronic PRO reports are well received by patients compared to paper-and-pencil versions when the assign- ment was randomized $[32,35-37,40]$. However little attention has focused on the patients' own preference for paper-based or electronically-based questionnaires or on the acceptance of electronic questionnaires if patients are free to choose between the two options. Schaeffeler et al. found that, while levels of reliability and acceptance were high among patients with breast cancer, the patients' own preferences were not taken into consideration [40]. There were no previous studies of this type of patients with metastasis, and possible correlations between socio-economic status or state of health and the willingness to use ePRO were not much considered. This study offers some conclusions for clinical practice which could help to improve PRO surveys in breast cancer patients with metastasis or receiving adjuvant treatment. Thus, "age", "level of education", "state of health" and "computer skills" have all been identified as variables which affect patients' willingness to use this form of survey. The results of the study emphasize the need to take a detailed (social) history of patients as this will allow those patients where the context and state of health indicate that there may be a barrier to using electronic surveys to be identified in advance [51] and allow their need for 
support or preferences to be resolved early on. The findings also emphasize the necessity of focusing on the user-friendliness of e-based surveys and (after identifying the barriers) the importance of optimizing their ease of use. The findings also offer some hints to supervising researchers or physicians about the importance of taking individual needs and other influences into account, even within the setting of research studies. Further studies will be necessary to elucidate how to reach patients lacking a sufficient knowledge of German and with few or no computer skills.

\section{Conclusions for Practice}

$\nabla$

Currently, the majority of female patients with breast cancer would prefer ePRO surveys to be done as part of routine clinical examination. Higher age and metastases were identified as barriers to the prospective participation of patients in ePRO surveys. If certain conditions with regard to age, educational level and current state of health are present, support should be offered to ensure that patients are willing to participate as this will underpin the validity of the survey. It would be useful to focus on the ease of use of ePRO applications and design them to be more patient-oriented.

\section{Conflict of Interest \\ $\nabla$}

The authors declare no conflict of interest.

\author{
Affiliations \\ ${ }^{1}$ Department für Frauengesundheit, Universitätsklinikum Tübingen, Tübingen \\ 2 Forschungsinstitut für Frauengesundheit, Universitätsklinikum Tübingen, \\ Tübingen \\ ${ }^{3}$ Abteilung Psychosomatische Medizin und Psychotherapie, \\ Universitätsklinikum Tübingen, Tübingen \\ ${ }^{4}$ Stabsstelle Sozialmedizin, Universitätsklinikum Tübingen, Tübingen \\ ${ }^{5}$ Abteilung für Allgemeine Frauenheilkunde und Geburtshilfe, \\ Universitätsklinikum Heidelberg, Heidelberg \\ ${ }^{6}$ Frauenklinik, Universitätsklinikum Erlangen, Erlangen
}

\section{References}

1 Swain SM, Kim SB, Cortés J et al. Pertuzumab, trastuzumab, and docetaxel for HER2-positive metastatic breast cancer (CLEOPATRA study): overall survival results from a randomised, double-blind, placebo-controlled, phase 3 study. Lancet Oncol 2013; 14: 461-471

2 Fasching PA, Brucker SY, Fehm TN et al. Biomarker für Patientinnen mit metastasiertem Mammakarzinom und das PRAEGNANT-Studiennetzwerk. Geburtsh Frauenheilk 2015; 75: 41-50

3 Weide R, Mergenthaler U, Pandorf A et al. Verlängertes Überleben von Patientinnen mit metastasiertem Brustkrebs im Versorgungsalltag: Ergebnisse einer retrospektiven Studie in einer onkologischen Schwerpunktpraxis 1995-2005. Onkologie 2009; 32: 107

4 Gennari A, Conte P, Rosso R et al. Survival of metastatic breast carcinoma patients over a 20 -year period: a retrospective analysis based on individual patient data from six consecutive studies. Cancer 2005; 104: $1742-1750$

5 Tai P, Yu E, Skarsgard D et al. Validation of the lognormal model for prediction of long-term survival rates from short-term follow-up data in stages III and IV breast cancer: a 22-year follow-up study. Curr Oncol 2003; 10: 191-194

6 Tai P, Yu E, Vinh-Hung $V$ et al. Survival of patients with metastatic breast cancer: twenty-year data from two SEER registries. BMC Cancer 2004; 4: 60

7 Todorović-Raković N, Nesković-Konstantinović Z, Nikolić-Vukosavljević D. Metastatic breast cancer survival according to HER2 and Topo2a gene status. Dis Markers 2009; 26: 171-180
8 Cetin K, Christiansen CF, Sværke C et al. Survival in patients with breast cancer with bone metastasis: a Danish population-based cohort study on the prognostic impact of initial stage of disease at breast cancer diagnosis and length of the bone metastasis-free interval. BMJ Open 2015; 5: e007702

9 Ahn SG, Lee HM, Cho SH et al. Prognostic factors for patients with boneonly metastasis in breast cancer. Yonsei Med J 2013; 54: 1168-1177

10 Mehta RS, Barlow WE, Albain KS et al. Combination anastrozole and fulvestrant in metastatic breast cancer. N Engl J Med 2012; 367: 435-444

11 Jackisch C. Metastasiertes Mammakarzinom: Längeres und besseres Überleben. Dtsch Arztebl 2014; 111: 18-23

12 RKI (Robert Koch-Institut). Krebs in Deutschland 2009/2010, Berlin 2013. Online: http://www.rki.de/DE/Content/Gesundheitsmonitoring/ Gesundheitsberichterstattung/GBEDownloadsB/KID2013.pdf? _blob=publicationFile; last access: 10.12.2015

13 Heil J, Gondos A, Rauch G et al. Outcome analysis of patients with primary breast cancer initially treated at a certified academic breast unit. Breast 2012; 21: 303-308

14 Kunze U. Mammakarzinom: Epidemiologie und Risikofaktoren. J Gastroenterol Hepatol Erkr 2011; 9: 38-40

15 Gondos A, Bray F, Hakulinen Tet al. Trends in cancer survival in 11 European populations from 1990 to 2009: a model-based analysis. Ann Oncol 2009; 20: 564-573

16 Jemal A, Siegel R, Xu J et al. Cancer statistics, 2010. CA Cancer J Clin 2010; 60: 277-300

17 Albert US, Altland H, Duda V et al. 2008 update of the guideline: early detection of breast cancer in Germany. J Cancer Res Clin Oncol 2009; 135: 339-354

18 Winzer KJ. [Diagnosis and treatment of breast cancer]. Chirurg 2005; 76: 803-816

19 Ly BH, Nguyen NP, Vinh-Hung $V$ et al. Loco-regional treatment in metastatic breast cancer patients: is there a survival benefit? Breast Cancer Res Treat 2010; 119: 537-545

20 Dufresne A, Pivot X, Tournigand C et al. Impact of chemotherapy beyond the first line in patients with metastatic breast cancer. Breast Cancer Res Treat 2008; 107: 275-279

21 Schneeweiss A, Ruckhäberle E, Huober J. Chemotherapie des metastasierten Mammakarzinoms - ein Anachronismus in der Ära der personalisierten, zielgerichteten onkologischen Therapie? Geburtsh Frauenheilk 2015; 75: 574-583

22 Seeber S, Welt A. Das metastasierte Mammakarzinom. Umsetzung des Fortschritts in die onkologische Praxis. best practice onkologie 2008; 3: $4-15$

23 Sayer HG, Claßen J, Budach W et al. Therapie des metastasierten Mammakarzinoms. Onkologe 2002; 8: 874-879

24 Smith I. Goals of treatment for patients with metastatic breast cancer. Semin Oncol 2006; 33 (1 Suppl. 2): S2-S5

25 Gerber B, Freund M, Reimer T. Rezidiviertes Mammakarzinom. Therapiekonzepte zum Erhalt der Lebensqualität. Dtsch Arztebl Int 2010; 107: 85-91

$26 \mathrm{NIH}$ National Cancer Institute. Adjuvant and neoadjuvant therapy for breast cancer. 2009. Online: http://www.cancer.gov/types/breast/ adjuvant-fact-sheet; last access: 01.02.2016

27 Bernhard J et al. Patient-reported outcomes with adjuvant exemestane versus tamoxifen in premenopausal women with early breast cancer undergoing ovarian suppression (TEXT and SOFT): a combined analysis of two phase 3 randomised trials. Lancet Oncol 2015; 16: 848-858

28 Alzabaidey FJ. Quality of life assessment for patients with breast cancer receiving adjuvant therapy. J Cancer Sci Ther 2012; 4: 51-55

29 IQWiG. Allgemeine Methoden, 2015. Online: https://www.iqwig.de/ download/IQWiG_Methoden_Version_4-2.pdf; last access: 20.01.2016

30 DIMDI. Der Stellenwert von Patient Reported Outcomes (PRO) im Kontext von Health Technology Assessment (HTA). HTA-Bericht 2011. Online: http://portal.dimdi.de/de/hta/hta_berichte/hta220_bericht_de. pdf; last access: 10.12.2015

31 Glaeske G. Patientenorientierung in der medizinischen Versorgung. Vorschläge zur notwendigen Weiterentwicklung und Umgestaltung unseres Gesundheitswesens. WISO Diskurs (Friedrich-Ebert-Stiftung), 2011. Online: http://library.fes.de/pdf-files/wiso/07806.pdf; last access: 10.12 .2015

32 Wintner LM, Giesinger JM, Kemmler G et al. Verwendung und Nutzen von Patient-Reported Outcomes in der onkologischen Behandlung: eine Übersicht. Wien Klin Wochenschr 2012; 124: 293-303 
33 Clauser SB, Ganz PA, Lipscomb J et al. Patient-reported outcomes assessment in cancer trials: evaluating and enhancing the payoff to decision making. J Clin Oncol 2007; 25: 5049-5050

34 Lipscomb J, Reeve BB, Clauser SB et al. Patient-reported outcomes assessment in cancer trials: taking stock, moving forward. J Clin Oncol 2007; 25: 5133-5140

35 Velikova G, Keding A, Harley C et al. Patients report improvements in continuity of care when quality of life assessments are used routinely in oncology practice: secondary outcomes of a randomised controlled trial. Eur J Cancer 2010; 46: 2381-2388

36 Abernethy AP, Zafar SY, Uronis $H$ et al. Validation of the Patient Care Monitor (Version 2.0): a review of system assessment instrument for cancer patients. J Pain Symptom Manage 2010; 40: 545-558

37 Coons S, Gwaltney C, Hays $R$ et al. Recommendations on evidence needed to support measurement equivalence between electronic and paperbased patient-reported outcome (PRO) measures: ISPOR ePRO Good Research Practices Task Force report. Value Health 2009; 12: 419-429

38 Velikova G, Wright EP, Smith AB et al. Automated collection of qualityof-life data: a comparison of paper and computer touch-screen questionnaires. J Clin Oncol 1999; 17: 998-1007

39 Crawley JA, Kleinman L, Dominitz J. User preferences for computer administration of quality of life instruments. Drug Inf J 2000; 34: 137144

40 Schaeffeler N, Pfeiffer K, Grischke EM et al. Akzeptanz und Reliabilität eines elektronischen psychoonkologischen Screenings bei Patientinnen mit Brustkrebs: eine randomisiert-kontrollierte Studie. Psychother Psych Med 2013; 63: 374-380

41 Barentsz MW, Wessels H, van Diest PJ et al. Tablet, web-based, or paper questionnaires for measuring anxiety in patients suspected of breast cancer: patients' preferences and quality of collected data. J Med Internet Res 2014; 16: e239
42 Richter JG, Becker A, Koch T et al. Self-assessments of patients via Tablet $\mathrm{PC}$ in routine patient care: comparison with standardised paper questionnaires. Ann Rheum Dis 2008; 67: 1739-1741

43 Aaronson NK, Ahmedzai S, Bergman B et al. The European Organization for Research and Treatment of Cancer QLQ-C30: a quality-of-life instrument for use in international clinical trials in oncology. J Natl Cancer Inst 1993; 85: 365-376

44 Meraner V, Giesinger J, Kemmler $G$ et al. Development of a screening tool for the identification of psychooncological treatment need in breast cancer patients. Psychooncology 2009; 18: 974-983

45 Rabin R, de Charro F. EQ-D5: a measure of health status from the EuroQol Group. Ann Med 2001; 33: 337-343

46 Greiner W, Claes C, Busschbach IJ et al. Validating the EQ-5D with time trade off for the German population. Eur J Health Econ 2005; 6: 124 130

47 EORTC data center. EORTC QLQ C-30 Scoring Manual. 3rd ed. Brussels: EORTC (Eigenverlag); 2001

48 Pfaff H, Nitzsche A, Scheibler F et al. Der Kölner Patientenfragebogen für Brustkrebs (KPF-BK). Kennzahlenhandbuch. Köln: 2009. Veröffentlichungsreihe der Abteilung Medizinische Soziologie des Instituts für Arbeitsmedizin, Sozialmedizin und Sozialhygiene der Universität zu Köln (Forschungsbericht 1/2009). Online: http://www.imvr.de/ uploads/Kennzahlenhandbuch\%20KPF-BK\%202009\%20+\%20 Nutzungsbedingungen.pdf; last access: 10.12.2015

49 Neyer F, Felber J, Gebhardt C. Entwicklung und Validierung einer Kurzskala zur Erfassung von Technikbereitschaft. Diagnostica 2012; 58: 87-99

50 Nickel W, Born A, Hanns S et al. Welche Informationsbedürfnisse haben pflegebedürftige ältere Menschen und pflegende Angehörige? Z Gerontol Geriat 2010; 44: 109-114

51 Simoes E, Sokolov A, GrafJ et al. Klinische Sozialmedizin - warum? Von der epidemiologischen Assoziation zur personalisierten Sozialmedizin am Beispiel der Versorgung bei Mammakarzinom. Gesundheitswesen 2016; 78: 97-102 